\title{
Copyright Infringement on Parody Video: A Legal Perspective
}

\section{Nur Persmawati Sahar Putri}

Faculty of Law, Universitas Brawijaya, Indonesia

E-mail: ismunisma@gmail.com

\section{ARTICLE INFO}

\section{Keywords:}

copyright infringement;

parody video,

cinematographic

How to cite:

Putri, N. P. S. (2020).

Copyright Infringement on

Parody Video: A Legal

Perspective. Jurnal Media

Hukum, 27(2), 166-176

Article History:

Received: 06-05-2020

Reviewed: 28-05-2020

Revised: 02-12-2020

Accepted: 31-12-2020

\begin{abstract}
The study aims to find out and analyze copyright infringement related to making parody videos with cinematographic work content. The researcher analyzed one of the parody videos made by Shopee as advertising content. The parody video made came from one of the cinematographic works, namely Dilan 1991. The research method used was normative juridical. The approach used is the statutory approach and conceptual approach. The author examined that in Shopee ads, the making of the Dilon 2019 parody video satisfies the provision of Article 5 of Law Number 28 of 2014 on Copyright. Two rights are retained by a creator or copyright holder, namely moral rights and economic rights. Article 5 of the Copyright Act governs the moral interests of the author and copyright holder.The study indicates that the 2019 Dilon parody video made by Shopee as advertising content is a form of copyright infringement and is not included in fair use. That is because the parody video making violates the moral rights and economic rights of the creators of cinematography Dilan 1991.
\end{abstract}

DOI: 10.18196/jmh.20200149

Copyright (C) 2020 JURNAL MEDIA HUKUM. All rights reserved.

\section{Introduction}

The cinematographic work that has recently been favored by the Indonesian people is the 1991 film Dilan. Based on data from filmindoneisa.or.id which states that the 1991 Dilan film is ranked first in the best-selling film in Indonesia in 2019, with a total audience of up to five million. ${ }^{1}$ The film produced by Max Picture was released on February 28, 2019. The film received a positive response from the Indonesian public. Based on this fact, many of the parties made parody videos related to the 1991 Dilan film.

The making of these parody videos has been widely circulated on social media such as Instagram, Facebook, and YouTube. Many people make parody videos that resemble the 1991 Dilan film. But lately, Ody Mulya Hidayat as the producer of Max Picture has

\footnotetext{
1 Wartakota. (2019). Lampaui Target Lima Juta Penonton, Dilan 1991 Kokoh di Puncak Film TerlarisIndonesia2019. Avalibel from https://wartakota.tribunnews.com/2019/03/17/lampaui-target-5juta-penonton-dilan-1991-kokoh-di-puncak-film-terlaris-indonesia-2019, (retrieved on April17, 2020 )
} 
been disturbed by the parody video made by one of the well-known e-commerce companies, Shopee, as the content of the ads. The parody video entitled Dilon 2019 has many similarities to the 1991 Dilan film. The part that is said to be similar to the 1991 Dilan film is the use of names and fonts in the title, names of the players and the clothes worn by the ad content people. The parody video was made without permission from the creators of the 1991 film Dilan.

To balance the rights of copyright owners with the wider community's interests, the Copyright Law allows the use of one's works without the need for the author's permission. ${ }^{2}$ But in accordance with existing provisions. This provision is commonly called fair use. The principle of fair use is one of the principles that aims to balance owners' rights with society's interests. ${ }^{3}$ The "fair use" principle in the Law is regulated in Articles 43-51. Article 44 Paragraph (1) Letter (d) Copyright Law states that:

"The use, taking, duplication and or alteration of a Work and/or Related Rights product in whole or in part is not considered a copyright infringement if the source is mentioned or stated in full for the purpose; (d). performances or performances that are free of charge provided that they do not harm the creators' reasonable interests. "

Elucidation of Article 44 Paragraph (1) Letter (d) Copyright Law, a reasonable interest of the creator or copyright holder is "interest based on the balance in enjoying the economic benefits of a work".. ${ }^{4}$ The making of parody videos without permission from the creators of the 1991 Dilan Film can also be said to be fair use, but in this case, the making of the parody videos is used for advertising content gets commercial benefits. Based on the issue above, this study would analyze. This study analyzes the making of parody videos made by Shopee as advertising content, will make the parody videos be included in an act that violates copyright or is included in the category of fair use or fair use.

\section{Method}

This paper uses a normative legal research method because the focus of the study departs from the obscurity of norms, using an approach: statute approach, conceptual approach. The technique of tracing legal materials uses document study techniques, and the analysis of the study uses qualitative analysis.

\section{Analysis and Results}

Fulfillment of Copyright Infringement on Parody Videos with Dilan 1991 Cinematographic Content

\subsection{According to Article 5 Paragraph (1) Letter (e) Law Number 28 of 2014.}

As explained in the literature review, a creator or copyright holder has two rights, namely moral rights and economic rights. The moral rights of a creator and copyright holder are regulated in Article 5 of the Copyright Law. Article 5 Paragraph (1) Letter (e) of the Copyright Law states that:

\footnotetext{
2 Hutagalung, S.M. (2012). Hak Cipta. Jakarta: Sinar Grafika

3 Suparmono, G. (2010). Hak Cipta dan Aspek-Aspek Hukumnya. Jakarta:Rineka Cipta. p 15

4 Hidyah, K. (2017). Hukum HKI. Setara Press. Malang, p. 30
} 
"Moral rights as referred to Article 4 are rights that are eternally attached to an Author to:

e. Maintain their rights in the event of any distortion of the work, mutilation of the work, modification of the work, or anything that is detrimental to one's honor or reputation."

The researcher analyzed that the making of the Dilon 2019 parody video in Shopee advertising meets the requirement of Article 5 of Law Number 28 of 2014 on Copyright.

\subsubsection{Distortion of Creation.}

The Explanatory part of the Copyright Law defined that distortion of work is mutilation of original works or identity. ${ }^{5}$ Meanwhile, according to the Indonesian Dictionary (KBBI), the definition of distortion is a twist of facts, rules, and so on. ${ }^{6}$ The Law does not explain actions categorized as reversing facts, nor does it explain the purpose of twisting facts. 7 The mutilation of original works or identity of creation acknowledges a creation or a work that belongs to the original creator. It is considered a reversal of facts or identity when someone used another person's work without providing information relating to the copyrighted work holder.

The making of the Dilon 2019 parody video in Shopee advertising content is a form of distortion of creation since the parody video appeared in theaters before the start of the 1991 Dilan film and circulated on YouTube (Picture 1). Since the video does not provide the original creator's name, it leads to a presumption that the video is the original work of Shopee. This is different from the video circulated on YouTube (Picture 2).

In the second picture, the parody video shows the original video link, so based on this the act is not included in the distortion of the creation, because it still includes information related to the original creator, so it is not as if the creation is a video made by someone that does not adopt the Dilan 1991 film.

\section{Mutilation of Creation}

Mutilation of works when seen in the explanation of the Copyright Law that define the creation mutilation as the process or act of removing part of a work. ${ }^{8}$ Meanwhile, the meaning of mutilation in the Indonesian Dictionary (KBBI) is a process or an act of dismembering. ${ }^{9}$ In terms of removing part of a work, it is an act of cutting or not using someone's work completely. ${ }^{10}$ Dedy Kurniadi, an intellectual property rights observer, asserts that someone can commit copyright infringement in the form of creation mutilation if someone decapitates a copyrighted work. The consequences of the

\footnotetext{
5 Albar, A. F. (2018).Perlindungan Hukum Pengguna Musik Sebagai Latar dalam Youtube Menurut Undang-Undang Hak Cipta. Pactum Law Journal. ISSN: 2615-7837. p. 329 6KBBI.web.id/distorsi(18 April 2020)

7 Nugroho, S. A.( 2016). Penyelesaian Sengketa Arbitrase dan Penerapan Hukumnya. Jakrta: Prenadamedia Group. p. 25.

8 Explanatory part of Indonesian Copyright Law; Article 5 Paragraph (1) Letter (e)

${ }^{9}$ Kbbi.web.id/mutilasi(20 April 2020)

${ }^{10}$ Hidayah, U. K. (2008). Penanggulangan Pelanggaran Hak Cipta Terhadap Pembajakan CD/DVD (Studi Kasus di Jawa Tengah, Thesis, Program Pasca Sarjana Universitas Diponegoro.p 20
} 
beheading are detrimental to the creators or the original copyright holders. ${ }^{11}$

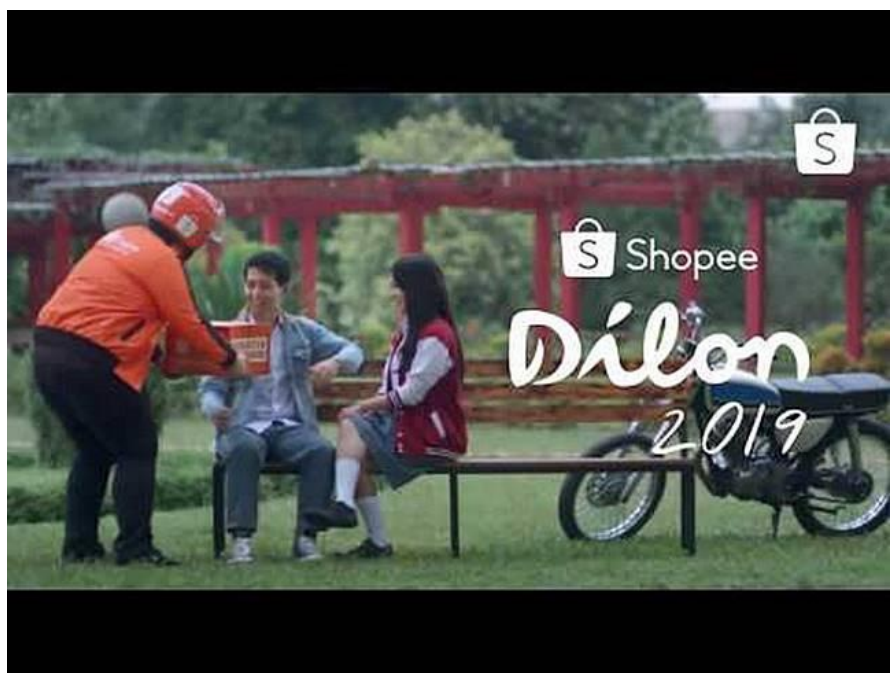

Picture 1. Parody Video by Shopee Ads

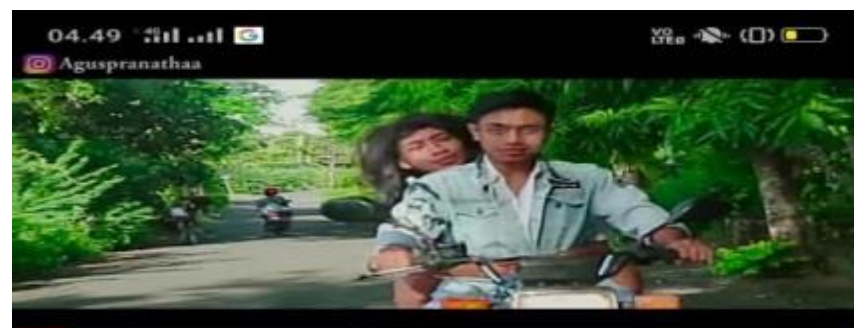

(2) Spoon Radio-SOC.. DOWNLOAD PARODY TRAILER DILAN 1991 396. $133 \times$ ditonton

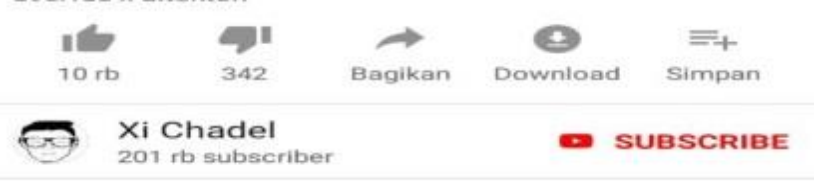

Dipublikasikan tanggal 21 Jan 2019

Teman teman terimakasih sudah menonton parody trailer dilan 1991 semoa terhibur :)

Jangan lupa tonton trailer aslinya yaa

https://www.youtube.com/watch?v=nwhB2...

Dilan : https://www.instagram.com/gaungggoo/

Milea : https://www.instagram,com/aguspranathaa

Picture 2. Parody Video on Youtube

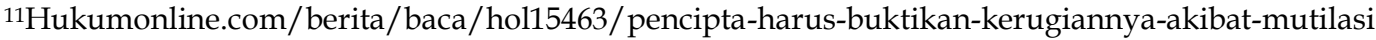
lagu(19 April 2020)
} 
The mutilation of creation when it is related to the making of the Dilon 2019 parody video is not included in the mutilation of the creation. This is because the Dilon 2019 parody video does not cut a creation, indeed in this case the Dilon 2019 parody video only has a duration of 30 minutes, different from the Dilan film which has a duration of 2 (two) hours a minute, in connection with this, it seems that the parody video is not the same as the original video, it can be said that this is an act of mutilation of a creation, but according to the author what is meant by mutilation of a creation is cutting a work exactly or not changing the creation but only cutting, what is meant by cutting exactly is cutting the work without changing the creation, for example, cutting the songs used in making mashup songs, in this case the cutting of the songs used as material for making mashup songs is cut exactly.

It is different from the Dilon 2019 parody video which made changes related to the original film, so in this case according to the author, the making of the Dilon 2019 parody video is not included in the category of creation mutilation because the production was not done by cutting the original creation exactly, but it just mimicking a few attributes does not cut a creation.

\subsubsection{Modification}

Based on the explanation of the Copyright Law, modification of a work can be fenied as changing the work. Meanwhile, the definition of modification in the Indonesian Dictionary (KBBI) is an alteration or change. Referred to as altering a work is an act of remodeling or diverting a creation to be different from the original. When it is related to the Dilon 2019 parody video, it is clear that the making of the Dilon 2019 parody video is an act of modification of a creation, this is because the Dilon 2019 parody video has changed several parts related to the original film, namely the 1991 Dilan film, these changes are related :

(1) Changing Player Name

In the 2019 Dilon Parody Video, the player names are Dilon and Melia, while in the original film, the players' names are Dilan and Milea.

(2) Change of Title

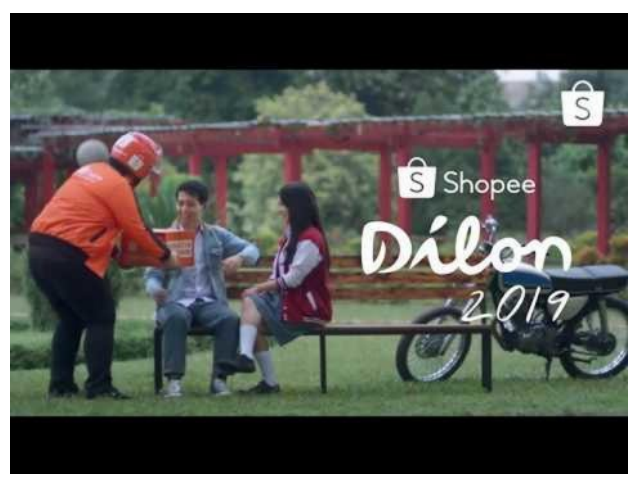

Picture 3. Parody Video by Shopee Adds

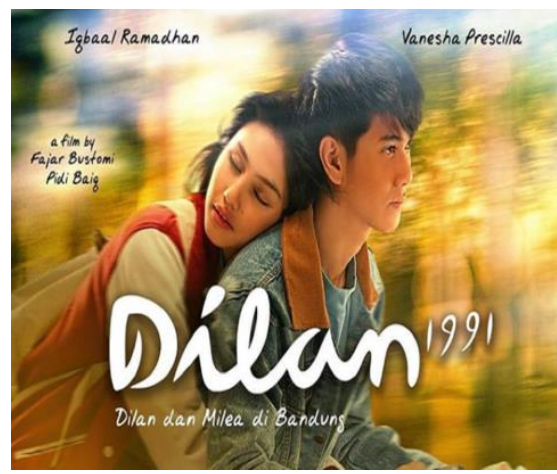

Picture 4. Dilan Film

In the Parody Video entitled Dilon 2019 (Picture 3), while in the Original Film it was titled Dilan 1991 (Picture 4), but in this case the title writing font on the parody video 
has the same as the original film, apart from the writing font, the color of the writing font also has similarities ( $\underline{\text { Table } 1}$ ).

\begin{tabular}{ll}
\hline Parody Videos & Original Movie \\
\hline Dilan : Nah ini dia, nih buat kamu, itu & Milea : 22 Desember \\
kacamata hitam biar kamu gak silau lihat & 1990 hari jadian \\
masa depan kita. & kami, hari dimana \\
(Well here it is, here for you, those are & aku merasa senang, \\
sunglasses so you don't dazzle to see & sangaat senang. \\
our future) & (December 22, 1990 \\
Melia : Dilon kamu bisa aja & our anniversary, the \\
(Aww you) & day I feel good, very \\
Melia 2: kalau aku, kalau aku & happy) \\
(if me?) & Dilan : cita-citamu \\
Dilon : ini mini compo. & apa sih ? \\
(this is mini compo.) & (what are your \\
Melia 2: kalau ini buat apa? & goals?) \\
(If this is what for?) & Milea : Pilot, kamu? \\
Dilon : itu buat kamu dengerin suaramu & (Pilot, you?) \\
aku kalau kamu lagi rindu. & Dilan :Menikah sama kamu. \\
(it makes you listen to my voice when & (Marry you) \\
you miss.) & \\
Dilon : dihatiku cuma ada satu Melia, kalau di shopee & \\
semua pasti ada. & \\
(In my heart, there is only one Melia, if in shopee & \\
everything is there.) & \\
\hline Table 1 Similatios dioque &
\end{tabular}

Table 1. Similarities dialoque

Table 1 clearly shows that the Dilon 2019 parody video completely changes the existing dialogue, so in this case, it is clear that the Dilon 2019 parody video made modifications related to the dialogue in the 1991 Dilan film. In addition to changing the dialogue or conversation in the 1991 Dilan film, the parody video also has four main actors. This is different from the original film, which has two main characters, namely Dilan and Milea, but the parody video has four main players, consisting of three melia and one Dilon.

Based on the existing explanation related to the modification of creation, it is clear that the making of the Dilon 2019 parody video is included in the category of modification of a creation, namely modification of the name of the actor or player, the title of the video and the dialogue in the video. In this case, the modification of a work should be done with the creators of the original film's permission because this includes violating the creators' moral rights. ${ }^{12}$

3.2 According to Article 9 Paragraph (1) Letter (d), and (g) of Law Number 28 of 2014 on Copyright.

As explained in the Literature Review, what is meant by economic rights is the exclusive right of a Creator or copyright holder to obtain financial benefits from his

${ }^{12}$ Soelistyo, H. (2011). Hak Cipta Tanpa Hak Moral. Jakarta:Rajawali Pers. 
copyright. ${ }^{13}$ Based on Article 9 Paragraph (1) Letters (d), and g in the Copyright Law, it explains the creators' economic rights. Article 9 Paragraph (1) Letters (d), and (g) of the Copyright Law states that

\section{"Creators or Copyright Holders as in Article 8 have economic rights to: d. Adaptation, Arrangement or Transformation of Works; g. Announcement of Creation."}

\subsubsection{Based on Article 9 Paragraph (1) Letter (d) of the Copyright Law}

Based on Article 9 Paragraph (1) Letter (d) of the Copyright Law, it is explained that a creator has the right to adapt, arrange or transform Works. ${ }^{14}$ In this regard, the researcher analyzed the Article, if it is related to the Dilon 2019 parody video.

The adaptation right is the right to give permission to adapt, which is meant by adaptation according to the explanation in Article 40 Paragraph (1) Letter (n) of the Copyright Law, which transforms works into other forms. In this case, the form's transformation into another form is like from a book to become a film. For example, Raditya Dika's films adapted from his novels. In this case, the Dilon 2019 parody video is an adaptation of the 1991 Dilan novel.

According to the Article 40 Paragraph (1) Letter (n) of the Copyright Law, informative is meant to change a form of creation to another form, for example, pop music to dangdut music. In this case, the Dilon 2019 parody video is transformative if it is made based on original work with the same type of work, but the format is changed to another form. In this case, if it is related to the Dilon 2019 parody video, it can be said that the Dilon 2019 parody video is an act of transformation from the 1991 Dilan film, this is because the parody video was changed in a format where initially a film was converted into a video which only lasted 30 minutes. Based on the explanation of the above transformation actions, transformation is changing a creation format into another format. This is clearly done in the Parodi Dilon 2019 video for the 1991 Dilan film.

An arrangement is an act of changing a work, an arrangement is usually made on work in the form of a song, for example, by adding lyrics or changing the instrument of a work, but in this case, the change is still based on the original work. If it is related to the Dilon 2019 parody video, the making of the parody video is not included in the form of an arrangement. This is because the arrangement is only carried out on a song, not a film or video.

\section{Based on Article 9 Paragraph (1) Letter (g) of the Copyright Law}

Article 9 Paragraph (1) Letter (g) of the Copyright Law states that a creator or copyright holder has the right to publish a work. Article 1 Paragraph 11 of the Copyright Law explains the meaning of the announcement of the work. "Announcement of a work is the reading, broadcasting, of a work using any means, whether electronic or non-electronic or doing it in any way so that a work can be read,

13 M.Hawin.( 2017).Isu-Isu Penting Hak Kekayaan Intelektual di Indonesia. Yogyakarta: Gadjah Mada University Press.p 10

14 Karo, R. P. P. (2015). (2015). Analisis Yuridis Perlindungan Hak Ekonomi Terhadap Buku Teks Pada Penerbit Gadjah Mada University Press Berdasarkan Undang-Undang Nomor 28 Tahun 2014 Tentang Hak Cipta. Jurnal Penelitian Hukum. Universitas Gadjah Mada. Volume 2, Nomor 1. p 39 
heard or seen by others".

The right to announce (performing right) is the right owned by a creator to convey or show his work to the public through broadcasting, performances, printing, and so on. The main thing in the right to publish is to show the work and show it to the public or the public. Based on this understanding, if it is related to the existence of the Dilon 2019 parody video, it can be said that the Dilon 2019 parody video is included in the category of announcing a creation, this is because the Dilon 2019 parody video was shown on a movie theater before the Dilan 1991 film show began, in addition to the cinema. The Shopee advertisement in the form of a Dilon 2019 parody video is also broadcasted on YouTube. It is clear that making the Dilon 2019 parody video is also included in the act of announcing a creation.

However, in this case, the Shopee ad's announcement in the form of a Dilon 2019 parody video was carried out without permission from the original creator. The act of announcing a work is the right of the original creators, so in this case, if the creators of the Dilon 2019 parody videos announce the parody videos created by them, there is a need for an agreement or request for permission from the owners or copyright holders of the original film. The act of announcing a copyrighted work without permission or without an agreement agreed upon by the parties concerned will certainly cause several losses for the original film's creators. In this case, it is one of the economic losses.

\section{The Dilon 2019 Parody Video status in the Copyright Law: Fair Use Principle.}

Based on the explanation in Articles 5 and 9 of the Copyright Law, it has been explained that what is included in copyright infringement is if an act committed by a person violates the moral and economic rights of the creator or copyright holder. It includes taking or using a work without permission can be said to be a form of copyright infringement, but not all acts of using a work without the permission of the creator or copyright holder are considered copyright infringement, some actions are not considered copyright infringement.

Based on the explanation in the literature review, fair use is a limitation regarding the use of the creator. ${ }^{15}$ The fair use principle is regulated in Article 43 to Article 49 of the Copyright Law. In this case, if it is related to the making of the Dilon 2019 parody video, which has experienced some controversy, the author will analyze the making of the Dilon 2019 parody video if it is related to the principle of fair use. Article 44 paragraph (1) letter $\mathrm{d}$ of the Copyright Law provides that:

"(1) The use, taking, duplication and or alteration of work and/or related rights product in whole or in substantial part is not considered as a copyright infringement if the source is mentioned or fully cited for the purposes of:

a. performance or performance which is free of charge provided that it does not harm the reasonable interests of the creator".

Suppose it is related to the making of the Dilon 2019 parody video. In that case, as analyzed above, the making of the Dilon 2019 parody video is included in the act of changing a creation in whole or in substantial part. This is evidenced by the changes

15 Pratama, B. (2015). Fair Use VS. Penggunaan yang Wajar Dalam Hak Cipta, http://BusinessLaw.Binus.ac.id/2015/01/31/Fair-Use-VS-Penggunaan-yang-Wajar-Dalam-Hak-Cipta/, Accessed on April 19, 2020 
related to the parody videocast, the video's title, the number of cast members, and the dialogue in the video.

Basically, changing a work owned by someone else is considered reasonable or is included in the fair use category, what is properly intended is that it means that the use or alteration of a work belonging to another person is allowed even without the permission of the original creator first, the number of videos proves that parody circulating on social media such as Instagram and YouTube. The parody videos were made without the original creators' permission or without permission from the creator of Dilan 1991 film.

Article 44 Paragraph (1) Letter (d) of the Copyright Law explains that taking, duplicating or modifying as a whole or substantially is allowed if it continues to include or mention the source, in connection with this the Dilon 2019 parody video does not include the source of the video, it is different from the parody video The second Dilan has been presented by the author above. In the parody video, both parties still include the source of the original video.

In addition, in Article 44 Paragraph (1) Letter (d) of the Copyright Law, it is emphasized that the act of taking, duplicating, or changing work is allowed if the source is still complete and is used for the purposes of performances or performances which are free of charge provided that it does not harm the reasonable interests of the creator. In this case, if it is related to the Dilon 2019 parody video as explained above, the making of the Dilon 2019 parody video is included in the activity of changing a creation. Based on Article 44 Paragraph (1) Letter (d), the act of altering a work without permission from the original creator is allowed as long as the performance or performance is free of charge and does not harm the reasonable interests of the creator.

In the Explanatory part of the Copyright Law, "reasonable interest of an Author or Copyright Holder" is defined as an interest-based on balance in enjoying the economic benefits of work. Referred to as "balance in enjoying economic benefits of a work" is an action taken by the parties which equally creates benefits or, in other words, does not cause harm to their party. If it is related to the Dilon 2019 parody video, parody video shows that are shown in theaters and on YouTube as advertisements are performance activities that are free of charge for the audience, but in this case, the e-commerce party, namely Shopee uses the parody videos as their advertising content. So based on this, Shopee certainly gets commercial benefits related to the Dilon 2019 parody video.

Based on the explanatory provisions in the Copyright Law, it has been stated that what is meant by "a reasonable interest of an Author or Copyright Holder" is an interest that is based on a balance in enjoying the economic benefits of a work. So that it is related to this because the Shopee uses the parody video as advertising content. With this ad's existence, it will benefit from commercial profits, thus in this case, there should be a profit-sharing with the creators of the 1991 Dilan film.

So, in this case, to determine a parody video is included in copyright infringement or is included in the fair use category, it can be seen from the purpose of making a parody video, if in this case, the purpose of making a video is for commercial purposes, of course, it is included in copyright infringement, but if the video is not used for commercial purposes or is only used for entertainment purposes, then it can be categorized as fair use. Or in this case, parody video is used for commercial purposes. Still, the video maker has asked for permission and there is a clear profit sharing 
agreement with the original creators. The act is not included in the category of copyright infringement.

In this regard, if it is related to the Dilon 2019 parody video that is used for Shopee advertising content, the act is included in the category of copyright infringement, not included in fair use or fair use, this is because the making of the Dilon 2019 parody video has violated moral rights. and the economic rights of the original creators. Violating moral rights, namely by taking historical actions and modifying a creation. Meanwhile, it violates economic rights, namely by adapting, transforming, and announcing a work. It is said to have violated it, because the making of the parody video was done without the permission of the original creators.

In addition to violating moral and economic rights, making the Dilon 2019 parody video, it was made to obtain commercial benefits. This is evidenced by the making of the Dilon 2019 parody video for the advertising content. In this situation, the Shopee gets commercial benefits. In connection with this, the Shopee should have entered into an agreement related to profit sharing to the creators of the 1991 Dilan film.

\section{Conclusion}

Dilan 1991 cinematographic parody video used as advertising content is a form of copyright infringement. It is not included in fair use because the parody video violates the moral and economic rights of the original creator. In other words, the action is the violation of Article 5 and Article 9 of the Copyrights Law of Indonesia.

\section{References}

Books:

Diantha, I. M. P. (2016). Metodologi Penelitian Hukum Normatif dalam Justifikasi Teori Hukum. Prenada Media.

Hidyah, K.(2017).Hukum HKI. Malang: Setara Press,

Hutagalung, S.M.(2012). Hak Cipta. Jakarta: Sinar Grafika

M. Hawin.( 2017).Isu-Isu Penting Hak Kekayaan Intelektual di Indonesia. Yogyakarta: Gadjah Mada University Press.

Nugroho, S. A.( 2016). Penyelesaian Sengketa Arbitrase dan Penerapan Hukumnya. Jakarta: Prenadamedia Group.

Soelistyo, H.(2011). Hak Cipta Tanpa Hak Moral. Jakarta: Rajawali Pers.

Suparmono, G. (2010). Hak Cipta dan Aspek-Aspek Hukumnya. Jakarta: Rineka Cipta.

\section{Journal Articles:}

Albar, A.F. (2018). Perlindungan Hukum Pengguna Musik Sebagai Latar Dalam Youtube Menurut Undang-Undang Hak Cipta. Pactum Law Journal. ISSN: 2615-7837. 
Hidayah, U. K. (2008). Penanggulangan Pelanggaran Hak Cipta Terhadap Pembajakan CD/DVD (Studi Kasus di Jawa Tengah, Thesis, Program Pasca Sarjana Universitas Diponegoro.

Karo, R. P. P. (2015). Analisis Yuridis Perlindungan Hak Ekonomi Terhadap Buku Teks Pada Penerbit Gadjah Mada University Press Berdasarkan Undang-Undang Nomor 28 Tahun 2014 Tentang Hak Cipta. Jurnal Penelitian Hukum, Volume 2, Nomor 1.

Pratama, B. (2015). Fair Use VS. Penggunaan yang Wajar dalam Hak Cipta, http://BusinessLaw.Binus.ac.id/2015/01/31/Fair-Use-VS-Penggunaanyang-Wajar-Dalam-Hak-Cipta/ accessed on April 19, 2020.

\section{Internet:}

Hukumonline.com/berita/baca/hol15463/pencipta-harus-buktikan-kerugiannyaakibat-mutilasi lagu (19 April 2020)

KBBI.web.id/distorsi (18 April 2020)

Kbbi.web.id/modifikasi (21 April 2020 )

Kbbi.web.id/mutilasi (20 April 2020)

Wartakota.(2019).Lampaui Target Lima Juta Penonton, Dilan 1991 Kokoh di Puncak Film Terlaris Indonesia 2019.Avalibel from https://wartakota.tribunnews.com/2019/03/17/lampaui-target-5-jutapenonton-dilan-1991-kokoh-di-puncak-film-terlaris-indonesia-2019, (Accessed 17 April 2020) 